\title{
What First Grade Teachers Reveal About Vocabulary Instruction: Aligning Instruction to the Common Core State Standards
}

\author{
Haley Olson ${ }^{*}$ and Johnnie Santos
}

\author{
University of Kansas, Lawrence, KS 66045, United States
}

\begin{abstract}
This mixed methods study examined the vocabulary knowledge and instructional practices of four grade 1 teachers in order to better understand how prepared teachers are to implement the First Grade English Language Arts Common Core State Standards (CCSS). Data collected included an audiotaped semi-structured interview, a teacher survey, video-recorded class vocabulary instruction, researcher field notes, and artifacts of class activities. Findings indicate that teaching experience is not a factor in the level of vocabulary instruction teachers provide. For example, veteran teachers in the analysis rely on traditional spelling tests and basal based vocabulary instruction to teach vocabulary, while the less experienced teachers utilize trade books to guide their instruction. However, veteran teachers provide vocabulary instruction daily, while less experienced teachers did not. Findings suggest that all teachers would benefit from professional learning opportunities related to vocabulary instruction and researchers are encouraged to investigate vocabulary instruction and its alignment to the CCSS with larger sample sizes in other districts and across all grade levels.
\end{abstract}

Keywords: Common core state standards, early literacy, professional development, vocabulary instruction.

\section{INTRODUCTION}

Vocabulary knowledge plays an important role in reading achievement. Helping students from low-income homes is especially important because research shows that students from lower income homes begin school with considerably fewer words in their vocabulary than that of their middle class peers (Hart \& Risley, 1995). Students from low socioeconomic backgrounds particularly need teachers to provide instructional methods that demonstrate students' understanding of vocabulary as many of these students begin their school career with limited vocabulary exposure. Supporting the vocabulary development of these students is important with the increased literacy demands placed on all students, even those in the primary grades, by the adoption of the Common Core State Standards (National Governors Association Center for Best Practices, 2010). Thus, the purpose of this study is to explore first grade teachers' vocabulary knowledge and instructional practices related to vocabulary. As the academic reading achievement among children of lower income homes declines (Reardon, 2013), this study helps in better understanding how teachers might better supported so that they can increase the quality of vocabulary instruction in the primary grades.

\section{PURPOSE}

Early vocabulary instruction has a significant relationship to literacy development (Biemiller, 2001), and providing effective instruction is particularly important for students from low socioeconomic (SES) backgrounds. That is, students from low SES homes often start school with

*Address correspondence to this author at the University of Kansas, Joseph R. Pearson Hall, Rm. 321, 1122 West Campus Rd., Lawrence, KS, United States; Tel: 785.317.7283; Fax: 785-864-5207;

E-mail: haleymarieolson@ku.edu significantly less vocabulary knowledge compared to their peers from middle SES backgrounds (Hart \& Risely, 2003). Therefore, teachers need the knowledge and skills to provide rich and multifaceted vocabulary instruction to increase student's word knowledge (Nagy, 2005). However, with higher expectations for student achievement in the CCSS, we are concerned that the level of instruction may not be sufficient to support student learning, and may magnify the increasing gap between students from low and middle SES homes. That is, some teachers, particularly those teaching students from low SES homes, may need different strategies for teaching vocabulary. Yet, before we plan for professional learning opportunities, we need to understand teachers' current beliefs, knowledge, and instructional practices regarding vocabulary. Thus, the present study seeks to determine teachers' beliefs, and knowledge about vocabulary instruction, and to identify the types of vocabulary instruction implemented in first grade classrooms serving students living in poverty.

\section{LITERATURE REVIEW}

Vocabulary knowledge is strongly related to students' reading comprehension, as well as their overall academic success (Beck, McKeown, \& Kucan, 2013; Tabors, Snow, \& Dickinson, 2001). Further, children's knowledge of vocabulary in first grade predicts reading achievement levels in high school (Cunningham \& Stanovich, 1997; Tabors et al., 2001)). That is, it is important to intervene in the early grades as research suggests the strong relation between vocabulary knowledge and reading comprehension, is strengthened over time (Baumann \& Kame'enui, 2004). However, learning oral vocabulary is not a simple process (Hart \& Risley, 1995), nor is accessing and comprehending the meaning of words in texts (Perfetti, Yang, \& Schmalhofer, 2008). Despite the complexity of vocabulary 
acquisition, research shows that rich vocabulary instruction does support students' ability to learn new words (Beck \& McKeown, 2007). As several researchers have indicated, our knowledge about effective vocabulary instruction in the primary grades is limited (Beck, et al., 2013; Coyne, Simmons, Kame'enui, \& Stoolmiller, 2004; Puhalla, 2011), and we find this disconcerting given the high expectations placed on student outcomes by the CCSS.

\section{EARLY LITERACY VOCABULARY INSTRUCTION}

Research indicates a strong relationship between vocabulary and later reading proficiency, especially when vocabulary instruction begins in the early literacy stages of learning (Cunningham \& Stanovich, 1997; Senechal, Oulette, \& Rodney, 2006; Silverman, 2007). For example, research shows that primary grade teachers need to provide direct and explicit vocabulary instruction (Coyne, et al., 2004; Puhalla, 2011; Silverman, 2007), and this can be accomplished through read alouds (Beck \& McKeown, 2007) among other instructional techniques. Also, instruction should include "rich explanations" of vocabulary definitions in order to increase students' word learning (Collins, 2009). Instruction also needs to be intense with respect to increased time to learn new words and multiple exposures of those words (Coyne, McCoach, Loftus, Zipoli, \& Kapp, 2009). Along the same lines, Baker, Santoro, Chard, Fien \& Park (2013) evaluated the read aloud intervention strategies of twelve $1^{\text {st }}$ grade teachers during a 19 week study to determine whether read aloud intervention teacher lessons occurring before, during, and after-reading techniques, resulted in an increase of performance among the intervention group. Findings suggest on some measures, the students in the intervention group outperformed students in the comparison group. In a study of similar intentions, Maynard, Pullen and Coyne (2010) analyzed the effectiveness of rich and basic instruction of target words with 224 first grade students randomly selected from three elementary schools. The researchers found that rich instruction was superior to both basic and incidental exposure to target words. The study concludes with a description of a three-step approach to vocabulary instruction. In a study on the receptive and expressive vocabulary of first grade students, Mandel, Osana, and Venkatesh (2013) studied the effects of Adapted Reciprocal Teaching (ART) on the receptive and expressive flight-word vocabulary of 50 first graders in order to determine whether the ART intervention would result in greater growth in the receptive and expressive flight-word vocabulary from a pretest to posttest. The study found that students in the ART group acquired significantly more target words than students in the control group.

While there is no doubt that direct and explicit vocabulary instruction helps students acquire vocabulary, we wonder, do teachers know how to implement such instruction to support their students?

\section{VOCABULARY KNOWLEDGE AND THE CCSS}

The CCSS expect teachers to teach with "rigor," which is defined as, teachers creating an environment in which each student is expected to learn at high levels and provide appropriate feedback and support to students so that they reach and demonstrate high levels of learning (Blackburn, 2008).

Further, the CCSS expect first grade teachers to instruct students to (a) identify words and phrases in stories or poems that suggest feelings or appeal to the senses (R.L.1.4); (b) ask and answer questions to help determine or clarify the meaning of words and phrases (R.I.1.4); determine or clarify the meaning of unknown and multiple-meaning words and phrases (L.1.4); (c) with guidance and support from adults, demonstrate understanding of figurative language, word relationships and nuances in word meanings, with guidance and support (L.1.5); and (d) to use words and phrases acquired through conversations, reading and being read to, and responding to texts, including using frequently occurring conjunctions to signal simple relationships. We position this study at the intersection of the reviewed literature that has focused on vocabulary instruction.

\section{THEORETICAL FRAMEWORK}

A theoretical framework that accounted for the depth and breadth of word knowledge is valuable in a study such as this. Therefore, the standard theory of word knowledge, where the meaning of words can be fully appreciated and understood only to the extent that they are analyzed in the context of connected oral speech or written text, framed this analysis (Anderson \& Nagy, 1991; Baker, Simmons \& Kameenui, 1998). The standard theory of word knowledge describes the process which, "word meanings can be characterized in terms of critical features" (Baker et al., 1998). In other words, when children utilize prior knowledge and known words in their oral and written practices, new words are better learned (Anderson \& Nagy, 1991). Further, vocabulary instruction should provide students with skills and strategies to learn words independently. That is, teaching words in isolation, utilizing words in lists, and offering standard definitions, limits the number of words students learn. Such one-dimensional approaches, goes against the instruction of vocabulary knowledge that leads to contextualized understanding (Paul \& O’Rourke, 1988).

\section{RESEARCH QUESTIONS}

Teachers are encouraged to teach vocabulary to support reading comprehension, as well as align their instruction to the CCSS. Yet, research indicates, "A substantially greater teacher-centered effort is needed to promote vocabulary development, especially in the Kindergarten and early primary years" (Biemiller, 2000). This is problematic because students' vocabulary knowledge directly affects their reading achievement. Understanding how prepared teachers are to provide vocabulary instruction is a first step in providing support to teachers. Thus, this study addressed the following questions:

1. How do teachers perceive the extent of their own knowledge of vocabulary instruction?

2. Do teachers' vocabulary instruction align with what first grade students are expected to know about vocabulary based on the Common Core State Standards?

3. To what extent are teachers proficient in their current level of vocabulary instruction based on the Rubric for Assessing Teacher Vocabulary Instruction? 


\section{METHODOLOGY}

\section{Research Design}

To identify teachers' perceptions of their level of vocabulary instruction, the extent of their instructional alignment of the CCSS for first grade students, and level of proficiency in vocabulary instruction, a mixed methods design was used to collect and analyze data.

\section{Rationale}

Although teachers are expected to align their instruction with the CCSS it is unclear what professional learning teachers have had about the CCSS in general, or vocabulary in particular. Nor is it clear if teachers have kept up with the growing body literature on this topic. Thus, there is a need to understand if teachers are prepared to teach students in a manner that aligns with the CCSS and what professional learning teacher might require.

\section{Site and Participants}

This study was conducted at Mason Street Elementary School (MSES; school and all participants were given pseudonyms), which is located on the outskirts of a major city in the Midwest portion of the United States. The student population at MSES was classified as $20 \%$ Latino, $49 \%$ European American, $30 \%$ African American, and 1\% other; and, over $91 \%$ of the students received free or reduced lunch.

Four first grade teachers were recruited to participate in the present study. Beth is a second year teacher who has taught first grade at MSES both years. Melissa has been teaching for nine years and this is her first year in first grade. Pat has been teaching seven years and is in her third year in first grade. Sandy has been teaching two years, both of them in the first grade.

\section{Data Collection and Sources}

To understand teachers' perceptions about vocabulary instruction and how they provide instruction, data was collected in January 2014 through May 2014. Data collected included an audiotaped semi-structured interview with each teacher (Appendix A) and 1 teacher survey (Appendix B). Data was also collected from observations and videorecordings of two class lessons over a three-week unit. Field notes were collected and the Rubric for Assessing Teacher Vocabulary Instruction (Appendix C) was used to identify the level of proficiency of each participant's vocabulary instruction. This rubric, adapted from Antonacci and O'Callaghan's Rubric for Assessing Academic Vocabulary Development (2011), is a theoretically sound instrument for identifying a teacher's expertise in developing their student's word knowledge. The same components of this rubric were used to design a measure of teacher instruction.

During the observations, copies of class activities or assignments that students completed served as artifacts for further data collection. The units of study among the classrooms varied; Melissa and Pat both utilized a three year old district adopted reading basal and were studying a unit on Transportation, while Beth and Sandy both used various trade books to study historical symbols and literature.

\section{Data Analysis}

Teacher interviews were transcribed verbatim and teacher surveys were collected. Both were then coded to identify common themes among teachers' perceptions of vocabulary instruction. To ensure trustworthiness, the research team met regularly to examine the transcripts the transcripts to understand teachers' perceptions about vocabulary instruction, particularly in light of their students' (Moustakas, 1994). Using a three-step technique, first, the transcripts were read and reread to gain a "holistic sense" of the data. Next, data was coded the following day, the coding trends examined and sorted into similar statements. For example, a common trend among the teachers in the study was the use of visual aids in their classroom to support vocabulary instruction. Another trend was that none of the teachers mentioned using formal vocabulary assessments in the classroom. Third, we formed meaning clusters (Moustakas, 1994; Creswell, 1998) by sorting the subordinate meaning units into broader clusters to determine themes. The following themes emerged: Teacher Expectations, Student Achievement, and Instructional Strategies and are illustrated in Table 1, Appendix D.

To determine teachers' present level of vocabulary instruction, a comparison of what teachers discussed to a list of "best practices" that is based in the literature, assisted in the analysis (e.g., direct and explicit instruction, multiple exposures to words). Further, the videotaped vocabulary lessons were evaluated using the Rubric for Assessing Teacher Vocabulary Instruction. Finally, the video recording was reviewed and field notes of class lessons were reread. Furthermore, photocopies of class activities were obtained to explore teachers' vocabulary instructional practices. Additionally, the data sources considered specific topics related to vocabulary acquisition to understand what teachers expected their students to learn about vocabulary (e.g., receptive and expressive vocabulary, depth of word knowledge). Finally, as per the CCSS, a measure of rigor in terms of vocabulary instruction was based on Revised Bloom's Taxonomy (Anderson, Krathwohl, Airasian, Cruikshank, Mayer, Pintrich, Raths, \& Wittrock, 2001) and the Webb's Depth of Knowledge chart (Webb, 1997). It is important to note that the purpose of analyzing the data was not to judge teachers, but rather to understand teachers' beliefs, knowledge, and instructional practices in order to determine if teachers might need professional learning in the area of vocabulary instruction. If so, we suggest this data will provide us guidance to develop appropriate support.

\section{Findings}

Our data, based on the six competencies of vocabulary instruction from the Rubric for Assessing Teacher Vocabulary Instruction, indicated that the participants' vocabulary instruction varied extensively in their instructional practices related to academic vocabulary (see Fig. 1). The first research question asked how the teachers' perceptions of personal vocabulary knowledge influence their vocabulary instruction. A three-step qualitative data analysis approach based on Moustakas' methodology, revealed three themes, which emerged from data regarding the teachers' perceptions. The common themes revealed from the teacher interview and survey include: Teacher Expectations, Student Achievement, and Instructional Content (see Appendix D). 


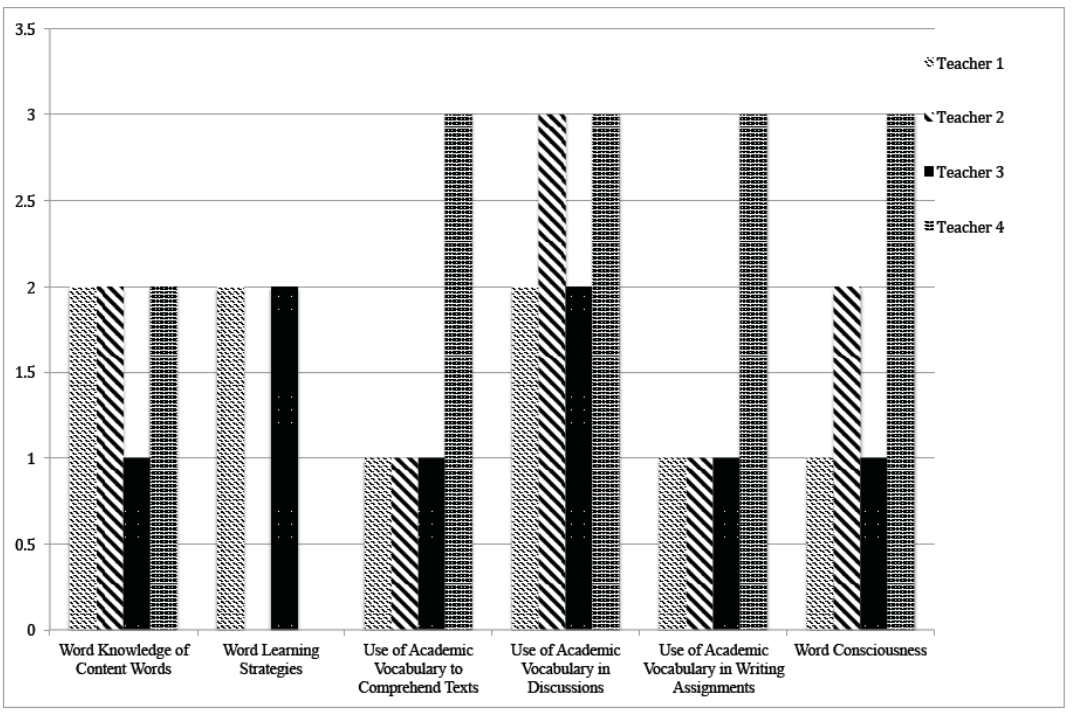

Fig. (1). Proficiency scores of participants on vocabulary instruction.

Teacher expectations regarding the extent of vocabulary instruction did not appear to be clearly communicated to the first grade teachers in this study. More specifically, the four teachers reported that they felt moderately confident in their overall understanding of what the CCSS expect them to teach to students, and only minimally confident in what the CCSS expects them to teach in relation to vocabulary. That said, teachers did report they believed they were teaching vocabulary adequately to their students. However, based on the Rubric for Assessing Teacher Vocabulary Instruction (Appendix C), all four teachers scored either Developing or Beginning teachers in all six domains (word knowledge of content words, word learning strategies, use of academic vocabulary to comprehend text, use of academic vocabulary in discussions, use of academic vocabulary in writing assignments, word consciousness). This shows that there is disconnect between teachers' perceptions of vocabulary instruction and actual classroom instruction.

Furthermore, assessment of student achievement appears to be another area where the teachers included in this study were unclear, $75 \%$ reporting that they were moderately confident in their knowledge of student achievement levels expected by the CCSS, but only minimally confident in their understanding of student achievement as it related to vocabulary in the CCSS. When reflecting on the videotaped vocabulary lessons, all four of the teachers did not use any measures of formative assessment to gauge student understanding. One teacher commented in her teacher interview that the students' role in learning is to "ask questions if they don't know what a word is. If they don't ask, I assume they know what it means." Another teacher answered that students should, "Use the word even if it is in the wrong way."

The final theme resulting from the triangulation of the data is Instructional Content, or the inclusion of vocabulary standards into their lessons within and outside of reading. Three of the four teachers indicated that they provide vocabulary instruction daily, both within reading lessons as well as other content areas. However, when asked if they were specifically teaching the five CCSS related to vocabulary, one teacher said she was addressing four of the five standards once a week, while the other three teachers reported that they rarely to never addressed any of the five standards. All four teachers indicated that they rarely to never addressed the fifth standard, "CCSS L.1.5: With guidance and support from adults, demonstrate understanding of figurative language, word relationships and nuances in word meanings" (National Governors Association Center for Best Practices \& Council of Chief State School Officers, 2010). This shows that, although the teachers are providing daily vocabulary instruction, they did not address the content expected by the CCSS. This finding is supported by the classroom observations. That is, two teachers were observed teaching spelling lessons and teaching word families, but not explicitly teaching the meaning of unfamiliar words to students.

In contrast, one teacher was observed teaching vocabulary that would appear in the book the students were about to read, but she did not explicitly state the definitions that accompanied the words, and the words were not show in context. Instead, the students were asked to discuss what they thought the word meant with a partner, but they were never given feedback as to whether or not their definition was correct. The fourth teacher was observed creating a vocabulary foldable with the students, where the students were given the word to write on the outside and then given the definition to write on the inside. In all four lessons, the students were provided with the words based on the curricular content and were given the words in isolation, rather than in context of a story or sentence.

The Rubric for Assessing Teacher Vocabulary Instruction, adapted from the Rubric for Assessing Academic Vocabulary Development (Antonacci \& O'Callaghan, 2011), was used to determine the level of proficiency on vocabulary instruction for each participant (see Fig. 1).

The second research question asks how the current level of vocabulary instruction aligned with the Common Core State Standards' expectations for first grade vocabulary knowledge. In the Word Knowledge of Content Words component of the rubric, the data confirms that the participants provide little or no definition to new words and rarely provide non-examples of the vocabulary words selected with three of the four participants scoring 2 out of 4 
points or Developing. While one teacher scored a 1 out of 4 points or Beginning. The teachers provided little instruction on the use of context clues overall on the Word Learning Strategies element of the rubric with two of the participants scoring a 0 , or Beginning, and two participants scoring a 2, or Developing. In the Use of Academic Vocabulary to Comprehend Text criterion, three of the participants did not provide instruction on content words before giving students a text, scoring a 1, or Beginning. Whereas, one of the participants modeled the use of context words to comprehend the text and made reference to several words in throughout the passage, therefore scoring a 3, or Proficient. In the Use of Academic Vocabulary in Discussions element of the rubric, preliminary data found that two of the teachers in this study often use content words in their class discussions with a low to average degree of accuracy during class discussions with two teachers scoring a 3, or Proficient, and two teachers scoring a 2, or Developing. Additionally, under the Use of Academic Vocabulary in Writing Assignments portion of the rubric, data suggests the majority of the teachers in this study use a large number of the content words only with a moderate degree of accuracy in writing assignments. More specifically, three of the participants scored a 1, or Beginning, while one participant scored a 3, or Proficient. Lastly, in the Word Consciousness portion of the rubric, two of the teachers did not demonstrate an interest in important or unusual words scoring a 1, or Beginning, while one participant scored a 2, or Developing, and one scored a 3, or Proficient.

\section{DISCUSSION}

Vocabulary knowledge plays an important role in students' reading achievement; therefore, teachers need to have a repertoire of instructional practices to meet the needs of their students. Further, the CCSS are placing greater demands on teachers and students in all grade levels, so teachers need to be well versed in the expectations of the CCSS. Identifying low vocabulary levels of children in early grades requires that teachers be prepared to intervene in effective ways to improve students' vocabulary knowledge. Thus, we explored teachers' perceptions about vocabulary and the types of vocabulary instruction they provided to their students. Despite the importance of vocabulary and the CCSS, the findings suggest the first grade teachers have a vague understanding of the rigor required by the CCSS in general, or how it pertains to vocabulary in particular. The results provide evidence that teacher's vocabulary lessons often do not align with CCSS, highlighting the need for specific professional learning in vocabulary instruction. Further, the teacher's responses revealed they did not feel prepared to teach the CCSS for vocabulary development. Thus, there seems to be a strong need for professional learning related to the CCSS and vocabulary instruction. These results are particularly noteworthy given that a large percentage of their students require vocabulary interventions as determined by low reading levels.

Our results demonstrate that there is much work to be done in terms of vocabulary instruction in first grade classrooms. During the time of the study, the participating district had recently purchased a new math curriculum, and as common practice, it had devoted the majority of professional development to supporting teachers in its successful implementation. Consequently, professional development opportunities in the school district had focused on math. However, during the time of this study, the adopted reading curriculum was five years old and new teachers have not been provided professional development on how to implement it. Further, due to the outdated curriculum, teachers were given the option of whether or not to use this curriculum in their classrooms or not, so there is some variation as to how reading is taught in the district and how this resource is used.

Nonetheless, teachers need adequate knowledge and skills about vocabulary instruction to provide effective instruction for their students (Nagy, 2005). They must understand what they are teaching and why they are teaching it before they can impact students learning. We suggest this is also true for teaching the Common Core State Standards. Teachers cannot provide adequate instruction if they first do not understand the standards and expectations of the CCSS.

A few caveats of the study need to be addressed. A small sample of teachers participated in this in-depth study and at only one site. Thus, including more teachers from varying districts and schools would provide additional information on the depth of teacher preparation in vocabulary instruction. The qualitative data were drawn from one survey consisting of open-ended questions and in general, sometimes openended questions lack the context that could lead to deeper analysis. Additionally, differing states that have also adopted the CCSS may provide various levels of teacher professional development regarding the first grade vocabulary standards. It is possible that these limitations may have affected the results of this study. However, the in-depth data gathered from triangulation reveal perceptions and conclusions that support the need to further investigate how and to what extent teachers are being prepared for vocabulary instruction that supports the shifts in the Common Core State Standards.

\section{EDUCATIONAL SIGNIFICANCE AND RELEVANCE TO EDUCATORS}

Vocabulary knowledge is important to reading comprehension, and vocabulary standards within the CCSS have refocused and revitalized teachers' awareness of its importance. Thus, to build on teachers' renewed interest in vocabulary instruction, particularly for young children considered "at risk" for academic success, and who are facing unique challenges at home, we chose to work with teachers in a high poverty community. It is important to note, professional learning on vocabulary is vital for all teachers, not only those who teach populations from low income backgrounds. However, we do suggest given the alarming patterns in terms of vocabulary knowledge of middle-class and disadvantaged first graders, it is important teachers who teach disadvantaged populations be prepared to provide early vocabulary intervention as the vocabulary gap widens rapidly. Socioeconomic status plays a role in vocabulary acquisition as it is imperative that all teachers who teach large populations of students from low income backgrounds be fully trained to teach direct vocabulary instruction related to the CCSS as the achievement gap demonstrates a particular urgency among this group. While we acknowledge the small number of participants in this study, we suggest our findings will provide educators with interesting insight into knowledge, beliefs, and practices related to vocabulary 
instruction for these first grade teachers, and identify challenges that other teachers may encounter when providing vocabulary instruction to their students. Further, we propose our findings will help to guide professional learning for teachers in similar school environments.

\section{IMPLICATIONS}

This study has implications for policy and practice related to vocabulary instruction for all students and, specifically, students from low-income homes. That is, teachers need to participate in professional learning opportunities regarding the CCSS in general, engage in vocabulary related self-study activities such as viewing webinars, reading professional research-based articles and seeking out resources suggested by vocabulary experts in the education field. The chart included provides teachers, whose district or campus may not provide vocabulary-specific professional development, with resources from which to teach themselves ways of enriching their own vocabulary instruction (Appendix E). Additionally, this study has implications for teacher preparation program, and suggests that some teachers may not be providing the vocabulary knowledge that is critical to teaching insightful vocabulary instruction in the classroom.

Teachers in this study viewed vocabulary instruction as either an unstructured time during read-aloud where new vocabulary words were introduced, or they viewed vocabulary instruction as teaching the meaning of words from a phonetically focused spelling list. In short, educators are not providing students with purposeful vocabulary instruction. Thus, all teachers need to have a stronger understanding of the link between vocabulary knowledge and reading achievement. However, teachers of first grade students from high poverty backgrounds should be provided early professional learning on vocabulary prior to the school year.

\section{CONCLUSION}

We have argued that there is a need to understand what first grade teachers know about vocabulary acquisition and vocabulary instruction. Further, the standard theory of word knowledge offers a way of analyzing current vocabulary instructional trends and can be used to analyze the current vocabulary instructional practices. Lastly, this analysis suggests enhanced support for teachers in terms of aligning vocabulary instruction to the CCSS is crucial, and a needs assessment concerning the professional development pertaining to the CCSS vocabulary requirements in first grade, essential.

\section{CONFLICT OF INTEREST}

The authors confirm that this article content has no conflict of interest.

\section{ACKNOWLEDGEMENTS}

We would like to thank the participants of this study for their willingness to be self-reflective and transparent. Also, thank you to our mentors and instructors, Dr. Barbara Bradley and Dr. Diane Nielsen for their guidance and feedback throughout this study.

\section{APPENDIX A}

\section{Teacher Interview Questions}

Teacher Pseudonym Teacher Years of Experience

1. Tell me about a typical vocabulary lesson in your classroom.

2. Tell me about how you choose the vocabulary words you teach.

3. Describe what you think a teacher's role in vocabulary instruction is?

4. Tell me what you think a student's role in vocabulary instruction is.

5. Tell me what you know about the Common Core State Standard Tier Vocabulary.

6. Tell me about the kinds of resources your students use to learn and understand new vocabulary words.

7. Tell me about how often you teach vocabulary.
a. Daily?
b. Weekly?
c. Varies?

8. Describe the types of vocabulary visual aids you currently have displayed on your classroom walls?

9. What do you tell your students about vocabulary words?

10. Tell me about how you assess students on the vocabulary you have taught.

\section{APPENDIX B}

\section{Teacher Survey Questions}

1. How many years have you been teaching:

2. How old are you:

Please rank your answers to the following questions by:

$0=$ No Understanding; $3=$ Moderate Understanding; $5=$ Advanced Understanding

3. Rank your understanding of CCSS expectations of teacher instructional levels

$\begin{array}{llllll}0 & 1 & 2 & 3 & 4 & 5\end{array}$

4. Rank your understanding of CCSS expectations of student achievement levels
$0 \quad 1$
2
3
45

5. Rank your understanding of CCSS expectations of teacher instruction in the area of vocabulary

$\begin{array}{llllll}0 & 1 & 2 & 3 & 4 & 5\end{array}$

6. Rank your understanding of CCSS expectations of student achievement in the area of vocabulary

$$
\begin{array}{llllll}
0 & 1 & 2 & 3 & 4 & 5
\end{array}
$$

7. Rank your understanding of the term "Tiers of Vocabulary" instruction.

$$
\begin{array}{llllll}
0 & 1 & 2 & 3 & 4 & 5
\end{array}
$$

8. How frequently do you explicitly teach vocabulary strategies in your daily reading instruction?

Rarely Once Daily 2-3 Times Daily 4+ Times Daily 
9. How frequently do you explicitly teach vocabulary strategies in your daily instruction of content areas outside of Reading?

\section{Rarely Once Daily 2-3 Times Daily 4+ Times Daily}

10. Briefly describe tactics you use to engage your students during vocabulary instruction.

11. I use a vocabulary list of words to drive my vocabulary instruction.
True
False

If true, who created the word list you use?

12. My school's English Language Arts/Reading curriculum dictates my vocabulary instruction.

True False

13. I use dictionaries during my vocabulary instruction.

True

False

14. Please list other common tools you use during your vocabulary instruction that were not previously mentioned.

15. How frequently do you explicitly teach vocab lessons that focus on identifying words and phrases in stories/ poems that suggest feelings or appeal to the senses?

$$
\text { Multiple Times Daily Once Daily }
$$
2-3 Times Weekly
Once Weekly Rarely/Never

16. How frequently do you explicitly teach vocab lessons that focus on asking and answering questions to help determine/clarify the meaning of words and phrases?
Multiple Times Daily

\section{2-3 Times Weekly}

Once Daily

Once Weekly Rarely/Never

17. How frequently do you explicitly teach vocab lessons that focus on students determining or clarifying the meaning of unknown and multiple-meaning words and phrases based on Grade 1 reading and content? (Examples: use sentence level context, use frequently occurring affixes, identify frequently occurring root words and their inflectional forms, etc.)
Multiple Times Daily
Once Daily
2-3 Times Weekly
Once Weekly Rarely/Never

18. How frequently do you explicitly teach vocab lessons that focus on using words and phrases acquired through conversation, reading and being read to, and responding to texts?
Multiple Times Daily
Once Daily
2-3 Times Weekly
Once Weekly Rarely/Never

19. How frequently do you explicitly teach vocab lessons that focus on students demonstrating understanding of figurative language, word relationships, and nuances in word meanings? (Examples: sort common objects into categories, define words by key attributes, distinguish shades of meaning, etc.)
Multiple Times Daily
Once Daily
2-3 Times Weekly
Once Weekly Rarely/Never

20. Is there anything about Reading and/or vocabulary instruction that you would like to share with us that has not already been touched on?

\section{Appendix C}

\section{Rubric for Assessing Teacher Vocabulary Instruction}

Adapted from the Rubric for Assessing Academic Vocabulary Development (Antonacci \& O’Callaghan, 2011)

\begin{tabular}{|c|c|c|c|c|}
\hline Criteria & Beginning (0-1 Point) & Developing (2 Points) & Proficient (3 Points) & Exemplary (4 Points) \\
\hline $\begin{array}{l}\text { Word knowledge of content } \\
\text { words }\end{array}$ & $\begin{array}{l}\text { Teacher instruction } \\
\text { demonstrates limited or no } \\
\text { inclusion of content words and } \\
\text { does not allow students to } \\
\text { provide simple definitions. }\end{array}$ & $\begin{array}{l}\text { Teacher instruction provides } \\
\text { simple definitions of content } \\
\text { words; does not provide examples } \\
\text { or non-examples of the word }\end{array}$ & $\begin{array}{l}\text { Teacher instruction provides } \\
\text { complete definitions of content } \\
\text { words and offers examples and } \\
\text { non-examples; teacher makes } \\
\text { some associations to related words }\end{array}$ & $\begin{array}{l}\text { Teacher provides extensive } \\
\text { definitions of content words with } \\
\text { numerous examples and non- } \\
\text { examples; offers many } \\
\text { associations to other related } \\
\text { words; provides opportunities to } \\
\text { compare and contrast content } \\
\text { words through specific features of } \\
\text { the words }\end{array}$ \\
\hline Word learning strategies & $\begin{array}{l}\text { Teacher does not model use of } \\
\text { context clues to determine } \\
\text { unknown words }\end{array}$ & $\begin{array}{l}\text { Teacher provides limited } \\
\text { instruction on use of context clues } \\
\text { to determine unknown words }\end{array}$ & $\begin{array}{l}\text { Teacher models use of context } \\
\text { clues with success to determine } \\
\text { unknown words }\end{array}$ & $\begin{array}{l}\text { Teacher models use of context } \\
\text { clues with a high degree of success } \\
\text { along with references to determine } \\
\text { unknown words }\end{array}$ \\
\hline $\begin{array}{l}\text { Use of academic vocabulary } \\
\text { to comprehend text }\end{array}$ & $\begin{array}{l}\text { Teacher does not model use of } \\
\text { content words to help } \\
\text { comprehend text. }\end{array}$ & $\begin{array}{l}\text { Teacher provides limited } \\
\text { instruction on use of content } \\
\text { words to help comprehend text } \\
\text { and makes reference of a few } \\
\text { content words throughout the } \\
\text { passage. }\end{array}$ & $\begin{array}{l}\text { Teacher models use of content } \\
\text { words to comprehend text and } \\
\text { makes reference to several content } \\
\text { words throughout the passage. }\end{array}$ & $\begin{array}{l}\text { Teacher models use of content } \\
\text { words to comprehend text and } \\
\text { makes reference to extensive } \\
\text { number of content words } \\
\text { throughout the passage/story. }\end{array}$ \\
\hline $\begin{array}{l}\text { Use of academic vocabulary } \\
\text { in discussions }\end{array}$ & $\begin{array}{l}\text { Teacher rarely uses content } \\
\text { words in class discussions }\end{array}$ & $\begin{array}{l}\text { Teacher uses some content words } \\
\text { during class discussions }\end{array}$ & $\begin{array}{l}\text { Teacher uses a large number of } \\
\text { content words during class } \\
\text { discussions }\end{array}$ & $\begin{array}{l}\text { Teacher uses an extensive number } \\
\text { of content words during class } \\
\text { discussions }\end{array}$ \\
\hline $\begin{array}{l}\text { Use of academic vocabulary } \\
\text { in writing assignments }\end{array}$ & $\begin{array}{l}\text { Teacher rarely uses content } \\
\text { words when modeling writing } \\
\text { assignments }\end{array}$ & $\begin{array}{l}\text { Teacher uses some content words } \\
\text { when modeling writing } \\
\text { assignments }\end{array}$ & $\begin{array}{l}\text { Teacher uses a large number of } \\
\text { content words when modeling } \\
\text { writing assignments }\end{array}$ & $\begin{array}{l}\text { Teacher uses an extensive number } \\
\text { of content words when modeling a } \\
\text { writing assignments }\end{array}$ \\
\hline Word consciousness & $\begin{array}{l}\text { Teacher does not facilitate an } \\
\text { interest in important or } \\
\text { unusual words }\end{array}$ & $\begin{array}{l}\text { Teacher facilitates some interest in } \\
\text { important and unusual words }\end{array}$ & $\begin{array}{l}\text { Teacher facilitates an interest in } \\
\text { important and unusual words by } \\
\text { having students record them }\end{array}$ & $\begin{array}{l}\text { Teacher facilitates a high interest } \\
\text { in important and unusual words; } \\
\text { students are asked to look up their } \\
\text { meaning, and record them }\end{array}$ \\
\hline
\end{tabular}




\section{Appendix D}

Table 1. Themes, frequencies, meanings, and selected examples of responses of participants' knowledge of vocabulary and instructional alignment to CCSS.

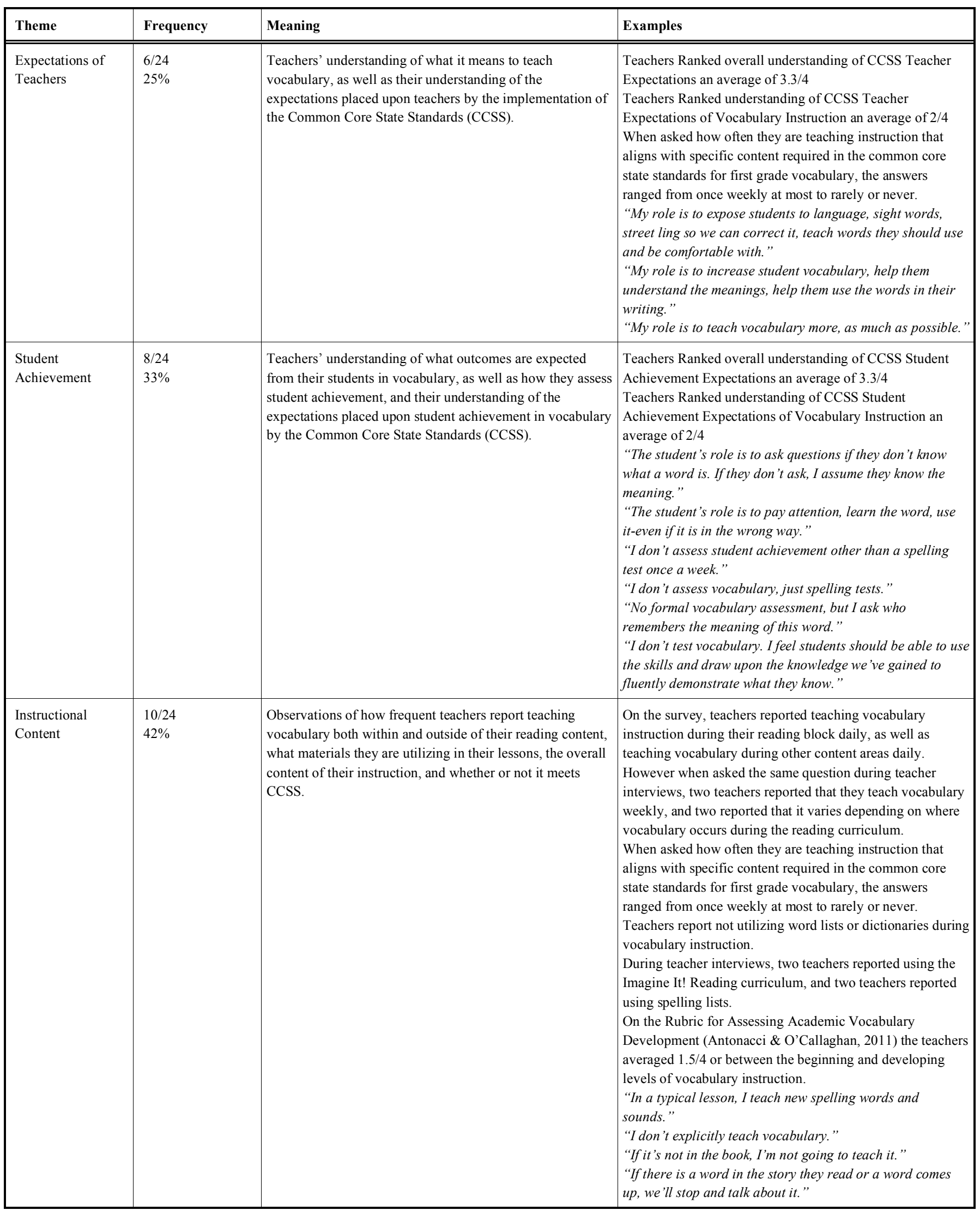




\title{
Appendix E
}

\section{Resources Available for Teachers to Enrich Their Own Vocabulary Instruction}

\author{
Resources for Enriching Your Own Vocabulary Instruction \\ Websites \\ $1^{\text {st }}$ Grade ELA/Vocabulary Acquisition CCSS. Retrieved from \\ http://www.corestandards.org/ELA- Literacy/L/1/ \\ Reading Rockets Vocabulary. (2014). Retrieved from \\ http://www.readingrockets.org/reading-topics/vocabulary \\ Beck, I., McKeown, M. \& Kucan, L. (2014). Taking delight in words: Using oral language to \\ build young children's vocabularies. Retrieved from \\ https://www.readingrockets.org/article/taking-delight-words-using-oral-language- build-young-childrens-vocabularies
}

\section{Video/Webinars}

Beck, I. (2014, December 9). Vocabulary Instruction. [Video file]. Retrieved from

https://www.youtube.com/watch?v=ltSJtcoOLf0

Marzano, R.J. (2013, January 22). Building Basic Vocabulary with Dr.

Robert J. Marzano. [Video file]. Retrieved from

https://www.youtube.com/watch?v=L_HN09W0s4o

\section{Books}

Antonacci, P.A. \& O'Callaghan, C.M. (2011). Developing Content Area Literacy. Thousand Oaks, CA: Sage Publications.

Marzano, R. \& Simms, J. (2013). Vocabulary instruction for the common core. Marzano Research Laboratory, Bloomington, IN.

Other

Rubric for Assessing Teacher Vocabulary Instruction (Appendix C)

\section{REFERENCES}

Anderson, L., Krathwohl, D., Airasian, P., Cruikshank, K., Mayer, R., Pintrich, P., Raths, J., \& Wittrock, M. (Eds.). (2001). A taxonomy for learning, teaching, and assessing: A revision of Bloom's taxonomy of educational objectives. New York: Addison Wesley Longman, Inc.

Anderson, R. C., \& Nagy, W. E. (1991). Word meanings. In: R. Barr, M. L. Kamil, P. B. Mosenthal, \& P. D. Pearson (Eds.), Handbook of reading research (pp. 690-724). New York: Longman.

Antonacci, P.A. \& O’Callaghan, C.M. (2011). Developing Content Area Literacy. Thousand Oaks, CA: Sage Publications.

Baker, S.K., Santoro, L.E., Chard, D.J., Fien, H. \& Park, Y. (2013). An evaluation of an explicit read aloud intervention taught in wholeclassroom formats in first grade. The Elementary School. 113(3), 331-358.

Baker, S.K., Simmons, D.C. \& Kame'enui, E.J. (1998). What reading research tells us about children with diverse learning needs: Bases and basics. Mahwah, NJ: Erlbaum.

Baumann, J.F. \& Kame'emui, E.J. (2004). Vocabulary instruction: Research to practice. New York: Guilford Press.

Beck, I.L., \& McKeown, M.G. (2007). Increasing young low-income children's oral vocabulary repertoires through rich and focused instruction. Elementary School Journal, 107(3), 251-271.

Beck, I.L., McKeown, M.G., \& Kucan, L. (2013). Bringing words to life: Robust vocabulary instruction $\left(2^{\text {nd }}\right.$ Ed.). New York, NY: The Guilford Press.

Biemiller, A. (2000). Vocabulary: The missing link between phonics and comprehension. Perspectives, The International Dyslexia Association, 26, 26-30.

Biemiller, A. (2001). Teaching vocabulary: Early, direct, and sequential. The American Educator, 25(1), 24-28.

Blackburn, B.R. (2008). Literacy from A to Z: Engaging students in reading, writing, speaking, and listening. Larchmont, NY: Eye on Education

Collins, M.F. (2009). ELL preschoolers' English vocabulary acquisition from storybook reading. Early Childhood Research Quarterly, 25(1), 84-97.

Coyne, M.D., Simmons, D.C., Kame'enui, E.J., \& Stoolmiller, M. (2004). Teaching vocabulary during shared storybook readings: An examination of differential effects. Exceptionality, 12(3), 145-162.
Coyne, M.D., McCoach, D.B., Loftus, S., Zipoli, R. Jr., \& Kapp, S. (2009). Direct vocabulary instruction in Kindergarten: Teaching for breadth versus depth. Elementary School Journal, 110(1), 1-18.

Creswell, J.C. (1998). Qualitative inquiry and research design : Choosing among five traditions. Thousand Oaks. CA: Sage Publications

Cunningham, A.E., \& Stanovich, K.E. (1997). Early reading acquisition and its relation to reading experience and ability 10 years later. Developmental Psychology, 33(6), 934-945.

Hart \& Risley (1995). Meaningful Differences. Baltimore: Brookes. Co.

Maynard, K.L., Pullen, P.C., \& Coyne, M.D. (2010). Teaching vocabulary to first-grade students through repeated shared storybook reading: A comparison of rich and basic instruction to incidental exposure. Literacy Research and Instruction, 49(3), 209-242.

Mandel, E., Osana, H.P. \& Venkatesh, V. (2013). Addressing the effects of reciprocal teaching on the receptive and expressive vocabulary of $1^{\text {st }}$-grade students. Journal of Research in Childhood Education, 27(4), 407-426.

Marzano, R. \& Simms, J. (2013). Vocabulary instruction for the common core. Bloomington, IN: Marzano Research Laboratory.

Moustakas, C. (1994). Phenomenological Research Methods. London, UK: Sage Publications.

Nagy, W.E. (2005). Why vocabulary instruction needs to be long-term and comprehensive. In: E. Hiebert \& M. Kamil (Eds.). Teaching and learning vocabulary: Bringing Research to Practice. (pp. 27-44) Mahwah, NJ: Erlbaum.

National Governors Association Center for Best Practices \& Council of Chief State School Officers. (2010). Common Core State Standards for English language arts and literacy in history/social studies, science, and technical subjects. Washington, DC: Authors.

Paul, P. V., \& O'Rourke, J. P. (1988). Multimeaning words and reading comprehension: Implications for special education students. Remedial and Special Education, 9(3), 42-52

Perfetti, C., Yang, C. \& Schmalhofer, F. (2008).Comprehension skill and word-to-text integration processes. Applied Cognitive Psychology, 22(3), 303-318.

Puhalla, E.M. (2011). Enhancing the vocabulary knowledge of first-grade children with supplemental booster instruction. Remedial and Special Education, 32(6), 471-481.

Reardon, S.F. (2013). The widening income achievement gap. Educational Leadership, 70(8), 10-16.

Senechal, M., Oulette, G. \& Rodney,D. (2006). The misunderstood giant: On the predictive role of vocabulary to reading. In: Neuman, S.B., 
Dickinson, D. eds. Handbook of early literacy research. Vol 2. pp. 173-182. New York, NY: Guilford Press.

Silverman, R. (2007). A comparison of three methods of vocabulary instruction during read-alouds in kindergarten. The Elementary School Journal, 108(2), 97-113.

Tabors, P., Snow. C \& Dickinson, D. (2001). Homes and schools together: Supporting language and literacy development. In: Dickinson, D.,
\& Tabors, P.O. (Eds.), Beginning literacy with language (pp. 331334). Baltimore: Brookes.

Webb, N. (1997). Research monograph number 6: Criteria for alignment of expectations and assessments on mathematics and science education. Washington, DC: CCSSO.

(C) Olson and Santos; Licensee Bentham Open.

This is an open access article licensed under the terms of the Creative Commons Attribution Non-Commercial License (http://creativecommons.org/licenses/by-nc/3.0/) which permits unrestricted, non-commercial use, distribution and reproduction in any medium, provided the work is properly cited. 